\title{
LEADING AMIDST COMPETING TECHNICAL AND INSTITUTIONAL DEMANDS: REVISITING SELZNICK'S CONCEPTION OF LEADERSHIP
}

\author{
MARYA L. BESHAROV \\ Cornell University \\ RAKESH KHURANA \\ Harvard Business School
}

December 2014

Forthcoming in Research in the Sociology of Organizations

PLEASE DO NOT CITE OR DISTRIBUTE WITHOUT AUTHORS’ PERMISSION 


\begin{abstract}
This chapter explores how Selznick’s approach to leadership can inform contemporary organizational theory and research. Drawing on Selznick’s writing in Leadership in Administration and related works, we characterize organizations as simultaneously technical entities pursuing economic goals and value-laden entities pursuing non-economic goals arising from their members and their role in society. These two aspects of organizations are deeply intertwined and in continual tension with one another, and the essential task of leadership is to uphold both - protecting and promoting values while also meeting technical imperatives. To do so, leaders establish a common purpose that includes values and ideals not just technical imperatives, they create structures and practices that embody this purpose, and they make organizational decisions and personal behavioral choices that are consistent with this purpose. We consider each task of leadership in turn, showing how Selznick’s ideas enrich and extend contemporary research on competing institutional logics, organizational design, culture, and identity, leadership, and meaningful work.
\end{abstract}

Keywords: Selznick, leadership, institutional theory, competing demands, meaning of work 
In our field of organizational behavior, Selznick is best known for TVA and the grass roots: A study in the sociology of formal organization (1949), a book on the federally-owned Tennessee Valley Authority (TVA) that Congress chartered in 1933 to build the electric and navigation infrastructure of the river basin between the Appalachian and Cumberland Mountains, a historically economically disadvantaged area in the southern United States. Selznick’s findings on the loose coupling between formal organizational structure and everyday behavior, as well as his discoveries about how the TVA's founding ideals were subverted as the corporation sought to navigate a complex external environment, challenged the then-dominant accounts of bureaucracy as a rationally-designed machine controlled by an agentic, unconstrained formal leadership (Merton, 1952; Weber, 1964). Several of his conclusions_including that an organization could shift from being a means to an end to becoming an end in itself; that powerful interests outside of an organization, including the state, exert an important influence and constraint on an organization's leaders; and that efforts at maintaining legitimacy are at the center of many organizational decisions—now constitute some of the core tenets of institutional theory, one of the most active and prominent perspectives in the field of organizational behavior (Davis, 2010).

Indeed, so powerful were Selznick’s insights about the inner-life of organizationswhere our human contradictions create within organizations continuous arresting tensions between formal goals and survival, organizational boundaries and the environment, and where organizational contradictions exert on individuals the oppositional pulls of materialism and meaning, substance and symbol—that contemporary research underplays Selznick’s central finding that both technical and institutional forces are often at work in organizations and that much of organizational life consists of the interplay between them (see Suddaby, 2010). 
Everyday experience in organizations confirms this notion that technical and institutional forces exist side by side. Even for highly institutionalized organizations such as Apple, IBM, or the Department of Defense, mobile phones have to make calls, computers have to add, and drones have to drop missiles. Take, for example, our own institution of higher education. When we teach a class, the technical elements move along predictably. Professors know the formal procedures for registering a class and grading student performance. When we walk into the classroom, students usually sit where we expect them to. The lights go on. Professors lecture. Students take notes. Classes start and end around the specified times. At other times, more distinctly institutional processes are at work. Hidden agendas, parochial interests, and worries about optics can and do drive decisions. Rules and procedures that accomplish little but are sanctified by time are carried out without protest. Longstanding traditions, such as a commencement or a festschrift, create a sense of filiation and continuity among community members and threats or changes to them provoke collective protest.

Selznick described this interplay of technical and institutional factors toward the end of

TVA:

\begin{abstract}
All formal organizations are molded by forces tangential to their rationally ordered structures and stated goals...As a result, the organization may be significantly viewed as an adaptive structure, facing problems which arise because it exists as an organization in an institutional environment...It follows that there will develop an informal structure within the organization which will reflect the spontaneous efforts of individuals and subgroups to control the conditions of their existence... As a consequence of the central status of constraint, tensions and dilemmas will be highlighted. Perhaps the most general sources of tension and paradox in this context may be expressed as the recalcitrance of the tools of actions. Social action is always mediated by human structures, which generate new centers of need and power and interpose themselves between the actor and his goal. Commitments to others are indispensable in action: at the same time, the process of commitment results in tensions which always have to be overcome (Selznick, 1949: 251-253).
\end{abstract}

Here Selznick emphasizes inherent tensions between the political, cultural, and value-laden aspects of organizational life, on the one hand, and those experienced as more technical, on the other. While there are important differences among political, cultural, and value-laden elements 
(March \& Olsen, 1976; Salancik \& Pfeffer, 1974), Selznick grouped them together under the heading of "institutional" and emphasized their distinction from the more purely technical realm in which efficiency and rationality reign supreme. Even as we recognize the complexity contained within Selznick's conception of the institutional, we adopt his approach in focusing on tensions between institutional and technical spheres of organizational life. It was these very tensions that Selznick himself sought to reconcile in his 1957 book Leadership in Administration $(L I A)$.

In LIA, Selznick builds on his main finding from TVA that the combination of technical and institutional pressures can lead even well-intentioned leaders to concede to external demands that threaten an organization's character, and he conceptualizes how leaders can overcome these pressures and uphold the integrity of the organization and the institutional values it embodies. He argues that through a combination of substantive and symbolic action, leaders can establish values and purposes that bring together diverse sub-groups of members and loosely-coupled organizational units into a coherent and meaningful whole—an entity with both character and integrity. He further shows how character and integrity can enhance an organization’s technical competence, enabling it to meet the demands of external constituencies on whom it depends.

In recent years, several scholars have discussed how Selznick’s approach to leadership, as articulated in LIA and related works, can inform contemporary institutional and leadership theory (Glynn \& Rafaelli, 2013; Kraatz, 2009; Washington, Boal, \& Davis, 2008). We join these scholars in highlighting how a Selznickian approach can enrich contemporary research, first by directing our attention to the role of values even in avowedly utilitarian organizations and, second by suggesting that the protection and promotion of values is an essential task of leadership. We also seek to extend this work by focusing on the persistent dualities and tensions 
between the institutional realm of values, culture, and politics, and the technical realm of efficiency, rationality, and administration. The central purpose of our chapter is to explain how these two realms are interrelated and to articulate how leaders can uphold institutional values while simultaneously meeting technical imperatives.

In so doing, we draw on and integrate disparate streams of work within organizational theory, one depicting institutional life as highly rational and technocratic, the other offering a conception of organizations as ritualized value, cultural, and political systems. The former usually explains organizational processes in terms of internal technical imperatives and view the role of leaders as purely utilitarian, giving us an under-institutionalized account of organizations in which leadership is argued to be agentic to the extent that it can directly affect economic performance (for a review of rational perspectives, see Pfeffer, 1997; Scott, 1992). The latter tends to explain organizational processes and outcomes in terms of extant forces operating at the level of the institutional field or environment and treats the actions of organizational leaders as largely symbolic. The result is an over-institutionalized account of organizations in which the role of leadership involves skilled performances and symbolic action designed to gain legitimacy and political support (Oliver, 1991; Westphal \& Zajac, 1994, 1998), or is even viewed, in the more extreme articulations of this perspective, as epiphenomenal (Meyer, 2010). We contend that leadership is at once symbolic and technical, equal parts "poetry and plumbing” (March \& Weill, 2005; see also Podolny, 2011). Moreover, we show how it is not separate from the realm of bureaucratic administration, as Weber contended (Weber, 1978; see also Krygier, 2012: 7071). Rather, these two realms are deeply interrelated. Apparently technical decisions, such as closing a manufacturing plant or entering a new market, have important symbolic implications. Likewise, symbolic actions that serve to define an organization's purpose and infuse meaning 
into organizational life frequently influence an organization's technical functioning as well. The role of leadership is to manage the interrelated and often contradictory demands that arise from the dual nature of organizations as technical and institutional systems. While doing so often involves choices, Selznick emphasizes that effective leadership cultivates integrative solutions that accomplish both the technical and the institutional.

Our argument is developed in three sections. The first section elaborates on the fundamental and often conflicting technical and institutional aspects of organizational life. Here we discuss how these two domains are overlaid rather than independent of each other, and we explain how this interplay leads to distinct leadership challenges above and beyond those involved in administrative management. Section two describes the tasks involved in navigating these challenges and upholding the integrity and character of the organization as a value-laden institution, not just a technical instrument. Here we elaborate on the leader's role in defining values and purpose, embodying purpose in the social structure, infusing meaning into organizational life, and "playing the part" in his/her own personal conduct. In the final section we discuss the implications of Selznick's conception of leadership for contemporary organizational theory and leadership education, and suggest some topics for future research.

\section{ORGANIZATIONS AS TECHNICAL AND INSTITUTIONAL SYSTEMS}

The term "organization"...suggests a certain bareness, a lean, no-nonsense system of consciously co-ordinated activities...An "institution," on the other hand, is more nearly a natural product of social needs and pressures—a responsive, adaptive organism (Selznick, 1957: 5).

The metaphorical distinction between "organization" and "institution" is central to Selznick's work and to understanding his conception of leadership. Because Selznick held that formal organizations almost always have elements of both "organization” and "institution,” to avoid confusion we use the terms technical and institutional to refer to these elements. Seen from 
a technical perspective, the organization is a mechanized structure consisting of roles, relationships, and tasks that can be deliberately modified to improve efficiency and performance. It is “an expendable tool, a rational instrument engineered to do a job” (1957: 5).

While Selznick recognized the importance of the technical features of organizational life, he departed from earlier theorists who assumed that formal structures fully explained behavior in organizations (Gulick \& Urwick, 1937; Taylor, 1911; Weber, 1964). Incorporating pragmatist and humanist lines of thought (Barnard, 1938; Follett, 1995; see also Metcalf \& Urwick, 1942), he argued that the Weberian image of formal organizations as rational and technical systems was incomplete. Organizations are also institutional systems_-adaptive social structures constituted by a complex of values embodied by organizational members themselves and the communities and societies within which organizations operate (see Krygier, 2012: 71-75; Selznick, 1992: 231238). As in other social groups, members of formal organizations develop unique practices and social relations within the context of their everyday interactions. Social networks, status hierarchies, interest groups, and informal norms of behavior emerge. This informal social system is embedded within, and often emerges out of, an organization's formal structure. Because bureaucratic rules are often too general and can rarely be applied to every specific situation, the need for judgment and discretion continually arises. Moreover, both informal and formal aspects of organizations develop in response to the opportunities created and the problems posed by the environment in which the organization operates.

From this perspective, the organization has a symbolic significance above and beyond its technical achievements. As Selznick famously wrote, it is "infuse[d] with values beyond the technical requirements of the task at hand” (1957: 17). Members sanctify its practices and imbue them with meaning (Harrison, Ashforth, \& Corley, 2009). External constituencies, too, attach 
meaning to the organization and expect it to uphold the values with which it is imbued. In $L I A$ Selznick sometimes suggests that this institutional aspect of organizations emerges over time, and in this way his work may appear to give primacy to the technical sphere. However, his study of the TVA, along with many of his later writings, reveals a fundamental concern with values and ideals that are present within organizations from the start, and a desire to understand how such values and ideals can be maintained as formal bureaucratic structures and technical systems develop (1949; 1992).

Selznick emphasized that technical and institutional systems, while conceptually distinct, are deeply intertwined and exist in continual tension with each other. Technical means have implications for values, and values depend on “mundane administrative arrangements” in order to be maintained (Krygier, 2012: 84-85; Selznick, 1957: 141). “Institutions embody values,” Selznick wrote, "but they can do so only as operative systems or going concerns. The trouble is that what is good for the operative system does not necessarily serve the standards or ideals the institution is supposed to uphold” (1992: 244).

These interdependencies and tensions pose significant challenges for organizations and their leaders. Selznick understood that it is all too easy for those in positions of power to become preoccupied with technical matters and to lose sight of the broader values on which the success of the institution rests (1957: 25-26). Even well-intentioned leaders frequently fail to perceive the cultural and symbolic effects of what appear to be "merely” procedural or operational choices. This was a central lesson Selznick drew from his study of the TVA. In LIA, he explains how the TVA's decision to carry out its agricultural activities in cooperation with local agencies not only affected the technical administration of the TVA's agricultural program but also had a broader influence on the character of the organization as a whole. In particular, this decision enabled the 
TVA to gain the support of powerful local and national constituencies and to prevent organizational dissolution long enough to successfully develop its core activities in the area of electrical power. Yet it also led the TVA to defend the interests of a particular, and relatively prosperous, farming constituency and to oppose conservation policies it was originally intended to promote. Actions taken to attain legitimacy and enhance survival thereby undermined the institutional integrity of the organization.

Contemporary studies of organizations across a range of industries offer further illustrations of how technical and institutional realms are intermingled and the challenges this poses for organizations and their leaders. For example, Hamilton's (2006) case studies of firms in the energy, accounting, and airline industries demonstrate the coupling between how an organization performs its technical functions and the extent to which it is seen to embody legitimate institutional values. Similarly, Kraatz and colleagues’ (2010) study of enrollment management in American liberal arts colleges suggests how formal structures can either support or undercut institutional values. The authors show that the adoption of "enrollment management”-an apparently innocuous administrative structure and corresponding set of practices in which admissions and financial aid offices are consolidated into a single organizational unit and decisions about financial aid are based on enrollment and financial targets— - had the effect of bringing market values into liberal arts colleges and undermining these organizations' historical commitment to equal access to higher education.

Selznick was not alone in recognizing these tensions between the technical and institutional aspects of organizational life. Yet other theorists who emphasized these tensions, such as Marx (1976), Foucault (1995), and Michels (1966), often viewed formal organization as fundamentally at odds with ideals and values. Michels, for example, argued that even 
organizations initially established as democratic and participatory would, over time, become oligarchies with power concentrated in the hands of a few and the ideals of democracy and participation subverted (see Selznick, 1992: 244-250). In contrast, Selznick, particularly in his later work, contended that while technical and political factors can potentially subvert institutional values, they can also be indispensable to the survival of these values. Even bureaucracy, for all its potential to become oppressive, may be necessary in some form for the achievement of values and ideals (Selznick, 1992: 273-288; Selznick, Nonet, \& Vollmer, 1980).

Selznick’s writings on leadership serve as a pragmatic guide for how leaders can guard against the tendency to lose sight of institutional values and succumb to technical imperatives. They are also an exercise in humanist science-showing how organizational theorists, and social scientists more generally, can and should address questions of values and ideals (Selznick, 2008). In the next section, we elaborate on Selznick’s practical prescriptions for leadership, and in so doing illustrate the role of values and ideals in Selznick’s theorizing.

\section{LEADERSHIP AS POETRY AND PLUMBING}

The plumbing of leadership involves keeping watch over an organization's efficiency in everyday tasks, such as making sure the toilets work and that there is somebody to answer the telephone... These aspects are essential for the smooth operation of organizations... Leadership also requires, however, the gifts of a poet, in order to find meaning in action and render life attractive (March \& Weill, 2005: 98).

Building on his understanding of the deep interconnections between the technical and institutional aspects of organizations, Selznick argued that leaders must concern themselves not only with the imperatives of administrative management that arise from the nature of organizations as technical systems, but also with the political, cultural, and value-laden demands central to the maintenance of the institutional system. In the words of Jim March, quoted above, Selznick understood leadership to involve both "poetry” and "plumbing.” Classical leadership 
theories rooted in a rational model of organizations highlight the plumbing, depicting leaders as rational actors seeking to maximize the efficiency of a technical system (Gulick \& Urwick, 1937; Thompson, 1967; Woodward, 1965). All too often, contemporary theories of leadership highlight only the poetry, framing leadership as a highly symbolic act of meaning creation (Kotter, 1999; Podolny, Khurana, \& Hill-Popper, 2005). Selznick, too, emphasized the symbolic work of leadership. Yet, he also recognized that administrative efficiency is equally necessary and, indeed, integral to the leader's ability to maintain institutional values, purpose, and integrity. He writes of leadership "in” administration, not leadership "of” administration or even leadership "and" administration. In this respect, his perspective differs in important ways from that of Max Weber, who recognized that formal organizations needed both leadership and administration but treated them as separate roles fulfilled by different individuals (Weber, 1978; see also Krygier, 2012: 70-71).

The deep interconnections between the poetry and plumbing of leadership are evident in the specific tasks of leadership Selznick highlighted, which we discuss in detail below: defining organizational values and purpose, maintaining institutional integrity, embodying purpose within the social structure of the organization, infusing meaning into organizational life, and "playing the part” by representing institutional values in one's personal interactions with internal and external constituencies. We show how even as these tasks highlight the role of values, meaning, and symbolic action, the maintenance of values is accomplished through, and is dependent on, the leader's ability to meet technical demands and uphold the formal, rational structure of the organization.

\section{Defining Organizational Values and Purpose}


We shall stress that the task of building special values and a distinctive competence into the organization is a prime function of leadership (Selznick, 1957: 27).

As the above quotation suggests, a primary task of leadership is to articulate and commit to values and purposes that transcend technical efficiency. Yet Selznick emphasized that the leader is not "free to do as he wishes, to mold the organization according to his heart's desire, restrained only by the quality of his imagination and the strength of his will” (Selznick, 1957: 27). Rather, in defining values and purpose, leaders must consider the values of society at large, of the particular communities within which the organization is embedded, and of the organization's members. It is only when administrative managers recognize and accept the constraints of these values that they progress to institutional leadership. They develop an understanding not just of what is required to sustain the organization's technical functioning but also of its place within the larger society. However, an emphasis on defining values and purpose does not imply that technical imperatives can be ignored. "To be sure,” Selznick wrote, "no institutional leader can avoid concern for the minimum conditions of continued organizational existence. But he fails if he permits sheer organizational achievement, in resources, stability, or reputation, to become the criterion of his success" (1957: 27). The leader's role, then, is to define and uphold values and purpose even while, and through, attending to the conditions necessary to ensure organizational survival.

In some organizations, values are present from inception. Liberal arts colleges, for example, were founded with a collective mission of providing liberal, humanistic education (see Kraatz \& Moore, 2002). Many other non-profit and governmental organizations similarly embody religious, educational, humanitarian, and environmental values and purposes from inception (Hwang \& Powell, 2009; Grant \& Sumanth, 2009). Increasingly, entrepreneurs are also founding for-profit organizations dedicated to social purposes. These "mission-driven 
businesses” and "social enterprises” use commercial means to pursue social ends (Boyd, Henning, Reyna, Wang, \& Welch, 2009; Haigh \& Hoffman, 2012; Smith, Gonin, \& Besharov, 2013). For example, the for-profit grocery company Whole Foods Market is dedicated to promoting health, wellbeing, and environmental sustainability. The firm maintains strict quality standards that prohibit the use of artificial additives and preservatives, donates $5 \%$ of after-tax profits to charity, provides financial support to entrepreneurs in developing countries from which it sources products, and incorporates green building techniques such as the use of recycled steel and biodegradable linoleum (Marquis, Besharov, \& Thomason, 2011). Tom's of Maine, a forprofit personal products firm, integrates its values and its business practices by buying from socially-responsible and often "fair trade”-certified suppliers, and using environmentally sustainable packaging (Austin \& Leonard, 2008). B-corporations and low-profit limited liability corporations have been recognized in many U.S. states as alternative legal forms that expand corporate accountability beyond shareholder concerns to explicitly include consideration of employee, community, and environmental interests when making decisions, and to protect directors when they take these stakeholders into account during the sale of a company (Bromberger, 2011).

The importance of articulating institutional values and purposes is not restricted to mission-driven organizations, socially-minded entrepreneurs, or companies with new types of corporate legal structures in which values and ideals are present from inception. Selznick emphasized that even more traditional business corporations have a "moral responsibility" to attend to societal values (1992: 345-354). When values are not present at inception, however, establishing them is particularly challenging, given the continual presence of technical imperatives. "Once an organization becomes a going concern, with many forces working to keep 
it alive, the people who run it can readily escape the task of defining its purposes. This evasion stems in part from the hard intellectual labor involved... In part, also, there is the wish to avoid conflicts with those in and out of the organization who would be threatened by a sharp definition of purpose, with its attendant claims and responsibilities” (Selznick, 1957: 25-26). Pressure to meet technical demands creates a tendency for leaders to avoid value commitments. Technical imperatives become seen as ends in themselves, and "the institution drifts, exposed to vagrant pressures, readily influenced by short-run opportunistic trends” (Selznick 1957: 25). While such organizations may survive, they fail to become vital and coherent social institutions (Selznick, 1996: 276). In the gambling and processed food industries, for example, many corporations persist and even thrive but are not perceived as morally aligned with broader social goals. In other industries, organizations may start off as values-driven but lose this focus over time. Banks and other financial services companies were initially seen as responsible corporate citizens contributing to the stability and prosperity of American society. In recent years, however, they appear to have drifted away from their founding value commitments toward opportunism and wealth accumulation for a handful of powerful insiders (Bogle, 2012; Kanter, 2011; Volcker, 2010).

In still other organizations, the task of defining values and purpose while simultaneously attending to technical imperatives is further complicated by the presence of multiple and potentially conflicting values. Particularly when multiple values are equally central to organizational functioning and yet imply contradictory actions, the very core of the organization is continually contested (Besharov \& Smith, 2014). This situation often arises when organizations confront pluralistic (Kraatz \& Block, 2008) or institutionally complex (Greenwood, Raynard, Kodeih, Micelotta, \& Lounsbury, 2011) environments, as when they lie at 
the intersections of divergent institutional fields (Morrill, 2006; Purdy \& Gray, 2009; Smets, Morris, \& Greenwood, 2012) or depend on multiple professional or occupational groups (D'Aunno, Sutton, \& Price, 1991; Dunn \& Jones, 2010; Heimer, 1999; Reay \& Hinings, 2009; Thornton, Jones, \& Kury, 2005). Establishing a shared purpose in such organizations not only requires overcoming conflict between technical and institutional imperatives; it also requires adjudicating between, and finding common ground among, internal sub-groups and external coalitions identified with potentially competing values (Ashforth \& Reingen, 2014; Battilana \& Dorado, 2010; Besharov, 2014). To do so, leaders must portray the organization as a consistent, coherent entity to insiders and outsiders alike, even though it is simultaneously comprised of potentially competing internal factions and subject to potentially competing external demands (see Pratt \& Kraatz, 2009). Leaders thereby create the possibility of redirecting conflicts between sub-groups toward more productive ends, such that 'they happen 'for' the organization, and within the constitutional framework it creates, rather than against or outside of it” (Kraatz \& Block, 2008: 255).

\section{Maintaining Institutional Integrity}

Among [the key problems of institutional leadership] is the defense of institutional integrity-the persistence of an organization's distinctive values, competence, and role (Selznick, 1957: 119).

While defining values and purpose is a central task of leadership, Selznick emphasized that values and purpose cannot be merely symbolic or espoused. Leaders must also ensure that they are enacted and made real, that they serve as a guide to organizational action. Selznick used the term "integrity" to describe this realized commitment to values and purpose. A central concept throughout Selznick’s work, integrity is perhaps best described as "fidelity to selfdefining principles” (Selznick, 1992: 322). It involves more than consistency, in that consistency 
does not require assessment of the purposes or values underlying action. At the same time, integrity sometimes involves inconsistent behavior, as when circumstantial or selective decisions are made in order to maintain fidelity to organizational values (Selznick, 1992: 323-324). Selznick had much to say about the importance of integrity within the legal and public sectors (Selznick, Nonet, \& Vollmer, 1980; Selznick, 1992). He also emphasized its significance in modern business corporations, in part because he understood it was particularly challenging to uphold in this context due to strong pressure for technical efficiency and profit maximization (Selznick, 1992: 345; 2000).

Paradoxically, while integrity is fundamentally about upholding the institutional system, its maintenance often depends on decisions that appear to be merely technical. We have described above how the integrity of the TVA was undermined by the technical and ultimately character-defining decision to cooperate with local agencies. Technical decisions can also enhance rather than weaken integrity. In their seminal chapter on organizational identity, for example, Albert and Whetten (1985) describe how the contributions that a business corporation makes to a local non-profit organization can over time lead to a commitment to civic engagement that becomes part of the firm’s “fundamental character” and distinguishes it from other businesses (Albert \& Whetten, 1985: 103). Other research suggests decisions about compensation and promotion systems can either enhance or work against an organization's capacity to “stay in integrity” (Jensen, 2010).

Just as technical decisions can influence organizational integrity, so too can the maintenance of integrity affect an organization's technical competence. When organizations uphold particular values, they develop and become recognized for having the capacity for a particular type of action. In the context of modern business corporations, for example, Selznick 
argued that defining and upholding values beyond mere technical efficiency could counter the “culture of shortsightedness” in American management and provide an enduring source of competitive advantage. “An apparent loss of competitive vigor has received considerable attention in recent years,” he wrote. “The decline, it is said, cannot be accounted for by external factors such as the international oil cartel or government regulation. Other countries have faced similar and even more severe constraints. The failure is one of management and leadership” (1992: 353). Leaders of modern corporations, he argued, tended to pursue narrowly defined technical interests, consistent with organizational theories that prescribed maximization of shareholder value as the sole purpose of the corporation (Stout, 2012; Khurana, 2007). If leaders instead sought to uphold values and maintain integrity, they could establish the long-term perspective and commitment to innovation necessary for sustaining their competitive position in an increasingly global economy. Seen in this light, Selznick’s theorizing about the role of leadership served as "a voice of resistance" to the dominant managerial theories of his time (1992: 354; see also 1996: 272).

In addition to its interdependence with technical imperatives, the maintenance of institutional integrity also requires a delicate balance of what Selznick termed "autonomy” and “responsiveness.” Organizations must remain faithful to self-defined values and therefore to some extent autonomous vis-à-vis external pressures. At the same time, organizations must be responsive to the claims and demands of external constituencies on whom they depend and whose wellbeing they affect (Selznick, 1992: 336; 2000). For example, multinational corporations that put a high premium on their consumer brands face the challenge of balancing cost efficiencies gained by outsourcing their production with the reputation risk that arises from using suppliers who violate labor laws or are not environmentally responsible. Firms such as 
Nike, Apple, and Levi Strauss that outsourced key tasks in order to focus their strategies on product design and marketing, as well as buffer themselves from the costs of maintaining expensive manufacturing facilities, now find themselves playing a more active managerial role in monitoring their global suppliers who sometimes are accused of labor violations and harmful environmental practices (Fair Labor Association, 2012a, b).

Selznick's concept of integrity has some parallels in contemporary research on organizational identity, the central, enduring, and distinctive characteristics that define "who we are" and "what we do" as an organization (Albert \& Whetten, 1985). Like identity scholars who conceptualize organizations as social actors with coherent identities defined by their public claims, commitments, and legal status (Whetten \& Mackey, 2002; Whetten, 2006), Selznick viewed organizations as capable of having selves that take action and are responsible for their actions. He further understood integrity to arise in part from an organization's commitments and responsiveness to external constituencies. Yet Selznick also emphasized the evolving and internally-driven nature of integrity, arguing that integrity was at risk when responsiveness to external constituencies came at the expense of fidelity to self-defined values (Pratt \& Kraatz, 2009; Selznick, 2000). In this way, his work foreshadows elements of an alternative perspective on organizational identity, one that treats identity as the emergent and socially-constructed product of sensemaking and negotiation among organizational members (Gioia, Schultz, \& Corley, 2000; Gioia, Patvardhan, Hamilton, \& Corley, 2013) and views leaders as playing a pivotal role in crafting such an identity (e.g., Gioia, Price, Hamilton, \& Thomas, 2010). His approach diverges from both perspectives on identity, however, in important ways. First, he reminds us that the maintenance of integrity, while certainly a symbolic and meaning-laden process, is interdependent with the accomplishment of an organization's technical tasks. Second, 
he emphasizes the moral underpinnings of institutional integrity. Leaders have an obligation, he contends, to articulate and uphold values and purposes that not only take account of the needs of internal and external constituencies but also resonate more broadly with fundamental human values (Selznick, 1992, see chapter 12).

\section{Embodying Purpose in Social Structure}

The task of leadership is not only to make policy but to build it into the organization's social structure (Selznick, 1957: 63).

Because organizations are technical as well as institutional systems, values are precarious. They are at risk of being eclipsed by technical demands. To maintain values and uphold institutional integrity in the face of continual technical imperatives, leaders must therefore build values and purpose into the social structure of the organization. By social structure, Selznick meant both formal and informal elements including the role structure and hierarchy as well as internal interest groups, shared beliefs, and power dependencies. Similar to contemporary theorists of organizational design and culture (e.g., Heskett, 2011; Nadler \& Tushman, 1997), Selznick viewed formal and informal elements as interconnected and held that leaders must shape both in order to uphold institutional values. He further argued that the tasks involved in doing so evolve over the course of an organization's history.

Early on, the leader's task is one of recruiting an "institutional core" of members whose own values reflect those of the organization and socializing these members to "create a unified group and give the organization a special identity" (Selznick, 1957: 106). Also at the early stage of institutionalization, leaders must create structures that protect "elites"—-those individuals most closely associated with the organization's values—from technical or utilitarian demands (see Krygier, 2012: 86-87). Without such autonomy, elites may succumb to technical pressures and 
lose sight of the values they are charged with upholding. Kraatz and colleagues' (2010) study of enrollment management (EM) in liberal arts colleges illustrates this possibility. As we have described earlier, EM is an apparently innocuous administrative structure and corresponding set of practices in which admissions and financial aid offices are consolidated into a single organizational unit and decisions about financial aid are based on enrollment and meeting financial targets. The adoption of EM introduced new, technical pressures into financial aid decisions and thereby undermined the autonomy of financial aid officers traditionally charged with maintaining the colleges’ value of equal access to higher education (Kraatz, Ventresca, \& Deng, 2010).

Once values and purpose are clearly established and no longer precarious, the focus of recruitment and organizational design changes. Organizations have less need for visionary innovators who can chart new directions and greater need for managers with administrative skill who can contribute to the maintenance of the existing institutional system. Also at later stages, there is a greater need for formalization. The establishment of explicit goals and rules, a system of authority, and channels of communication can all contribute to the maintenance of institutional values, reducing dependence on the personal inclinations of core or elite members. As this occurs, the broad base of members internalizes institutional values and starts to act in ways that promote them. As a result, "official aims and methods are spontaneously protected or advanced" (Selznick, 1957: 100). Decision making can ultimately become more decentralized, as leaders can depend on members across the organization to uphold values instinctively rather than through formal controls (Selznick, 1957: 106).

This description of the embodiment of purpose in social structure may suggest a linear process,but Selznick recognized that in practice it was cyclical and recursive. Leaders must 
continually adapt organizational structures to take account of varying circumstances, particularly those that influence the stability of institutional values. As values become established and administrative managers take over from visionary innovators, for example, there is a tendency for technical imperatives to guide organizational action to such an extent that institutional values again become precarious. At such times, selection of elite members who personally embody and are charged with maintaining institutional values again becomes necessary, along with organizational structures that protect elite autonomy (Selznick, 1957: 106).

In contemporary research, the elements that Selznick includes within social structure fall under the rubric of organizational design and culture, and much scholarship in this area echoes Selznick’s arguments. For example, research on organizational design emphasizes the interconnections between formal and informal structures and the importance of managing both simultaneously (Nadler \& Tushman, 1997). Scholars of organizational culture, meanwhile, highlight that both formal and informal structures, practices, and routines can embody, or undermine, organizational values and purpose. For example, Schein (2004), Martin (1992), Pfeffer (2010), and O’Reilly (1989) explain how rites and rituals, the design of physical space, and stories, legends, and myths all convey information about an organization's deeply-held values. Moreover, like Selznick, these scholars recognize that while symbolic features matter, values are also embedded in substantive organizational systems more typically associated with organizational management. The allocation of resources and rewards; recruitment, promotion, and removal of organizational members; and the establishment of organizational routines, systems, and processes can all affirm or undermine values (Schein, 2004).

The importance of embodying organizational purpose in social structure is further underscored by recent research on mission-driven organizations. This work shows, for example, 
that when formal structures are perceived by members to be inconsistent with the organization's espoused purposes, members make attributions of hypocrisy and may ultimately become disillusioned (Besharov, 2014; Cha \& Edmondson, 2006). For example, in her study of a socially responsible retail company that promotes natural foods and environmental sustainability, Besharov (2014) finds that policies such as the introduction of less "natural" products and the promotion of managers who do not recycle and compost waste generated moral outrage from employees who viewed these actions as violations of the organization's core purpose.

\section{Infusing Meaning into Organizational Life}

To create an institution we rely on many techniques for infusing day-to-day behavior with longrun meaning and purpose. One of the most important of these techniques is the elaboration of socially integrating myths. These are efforts to state, in the language of uplift and idealism, what is distinctive about the aims and methods of the enterprise (Selznick, 1957: 151).

When organizations have a distinctive character and purpose, members relate to them in ways that differ from what one witnesses in other organizations that lack these attributes. Members' interactions with the organization and their actions on its behalf are not just transactional but are imbued with meaning. As members internalize the organization's purpose, to the extent that their own actions further this purpose, they come to regard these actions as meaningful. They further view themselves as part of a valued community. They are motivated to exert effort on behalf of that community, to defend it when threatened, and to advocate on its behalf. As Selznick wrote in LIA, "emotional identification with the organization creates sources of energy that may increase day-to-day effort and, especially, be summoned in times of crisis or threat” (1957: 18). In this way, the experience of meaning through one's participation in an organization binds members to the organization and to one another. 
Selznick acknowledged that the infusion of meaning into organizational life could be instrumentally valuable, as members' identification with organizational values facilitates the accomplishment of an organization's technical objectives. Yet he emphasized that leaders have a moral obligation to infuse meaning into organizational life. Initially articulated in LIA, this message is more forcefully communicated in some of his later works, particularly The Moral Commonwealth (MC) (1992). Here he argued that leaders should seek to discover and articulate existing values that are meaningful to organizational members and society at large, not to create new meanings from whole cloth. Leaders must work with "natural” materials and recognize their limits and potential. They must find values that are "latent" not just in the organization but also in human experience more generally, and then make these latent values manifest to organizational members.

As the quotation at the start of this section suggests, one critical way in which leaders do this is by developing "socially integrating myths" that link the organization's activities to valued purposes and ideals. Too often organizational scholars treat myths as theories that should be subject to empirical verification (an exception is Schein, 2004). This is a conceptual error. A myth places something within the realm of the sacred and mystical. It provides a metaphorical account, conveying tacit knowledge and offering an explanation of otherwise mysterious events. In anthropology and sociology, myths are recognized as a means for creating solidarity and stability (Manning, 1977). Myths also serve internal psychic functions, helping people cope with fragmentation and angst.

Consistent with this view, the socially-integrating myths Selznick discusses in LIA are narratives leaders attach to their own and the organization's activities and through which they articulate connections between the daily work of the organization and the institutional values it 
was designed to uphold. Although Selznick recognized that such myths could serve strategic functions, he emphasizes their integrative capacity. The leader, Selznick explained, "requires some integrating aid to the making of many diverse day-to-day decisions, and the myth helps to fulfill that need. Sharp discrepancies between theory and practice threaten his own authority in the eyes of subordinates; conformity to the myth will lessen 'trouble' with outside groups. Not least important, he can hope that the myth will contribute to a unified sense of mission and thereby to the harmony of the whole” (1957: 152). Leadership in this sense is fundamentally an interpretive and symbolic act. Yet this interpretation and symbolism have material consequences for behavior. Moreover, Selznick suggests that beyond its instrumental role, the creation of meaning through "myth-making” fulfills a fundamental human need, one that is increasingly difficult to fulfill as traditional sources of meaning such as the family, religion, and other social institutions become fragmented in modern society. "Myth-making," he writes in LIA, "may have roots in a sensed need to improve efficiency and morale; but its main office is to help create an integrated social organism” (1957: 152).

Selznick's conception of myths and of the leader's role in creating them contrasts sharply with the use of "myth" in neoinstitutional theory, in which the term is often used to connote something divorced from reality and imposed on organizations from outside. For example, formal structures that comply with the demands of powerful external constituencies are described as "myth and ceremony" in contrast to the actual technical features of an organization (Meyer \& Rowan, 1977; Tolbert \& Zucker, 1983). Neoinstitutional scholars further emphasize that myths create fragmentation and decoupling internally, as organizations come to embody incompatible institutional and technical elements in order to demonstrate symbolic conformity with externallypromulgated myths (Meyer \& Rowan, 1977). In contrast, Selznick regarded myths as internally- 
generated, integrative narratives that have value precisely because of their symbolic nature. The leader's work is not to shield the organization from values held by external constituencies ("myths" in the language of neoinstitutional scholars) but rather to take them seriously and accept their constraints, to build these values into the social structure of the organization, to craft myths that make these values meaningful for members, and, as we will discuss in the next section, to embody these values in their own conduct and selves. Compared to neoinstitutional theorists, then, Selznick viewed leaders as having both greater autonomy and greater moral responsibility vis-à-vis their external (and internal) environments.

Perhaps not surprisingly, given the changing use of the term "myth," the leader's role in infusing meaning into organizational life has been largely neglected in contemporary institutional theory (Glynn \& Rafaelli, 2013; Podolny, Khurana, \& Hill-Popper, 2005; Suddaby, 2010). While institutional scholars have recently attended more closely to meaning-making processes within organizations and institutional fields (Murray, 2010; Suddaby \& Greenwood, 2005; Suddaby, Elsbach, Greenwood, Meyer, \& Zilber, 2010; Weber \& Dacin, 2011; Zilber, 2002, 2006, 2011), this work tends to use the term “meaning” in a value-neutral way to refer to what a particular object or behavior signifies to actors, not whether or not the object or behavior is meaningful to actors. Research in micro-organizational behavior more frequently focuses on meaningful work (e.g., Bunderson \& Thompson, 2009; Dobrow, 2013; Dobrow \& Tosti-Kharas, 201; Rosso, Dekas, \& Wrzesniewski, 2010), but the leaders role in creating meaning is often not emphasized (for exceptions see Grant, 2012; Pratt \& Ashforth, 2003).

For Selznick, infusing meaning was very much about transcending the utilitarian aspects of organizational life and creating a story or drama that rendered members' participation in the organization meaningful, and doing so was the responsibility of leaders. Although this 
perspective is largely absent in contemporary institutional and organizational behavior research, it is evident in practice. When one thinks of important organizations, the most vivid are those that not only create useful products and services but also generate meaningful experiences in the minds of those producing and consuming the products and services. Howard Schultz, the founder of Starbucks, for example, sought to create a "third place" in which consumers could find community in an increasingly fragmented urban society, while also attempting to treat his employees as whole people deserving of generous benefits, an economic stake in the company's success, and a voice in crafting its mission and values (Koehn, Besharov, \& Miller, 2008). Selznick urges us not to lose sight of the importance of meaningful experiences of this kindwithin organizational life and social life more generally. He further argues that infusing meaning, in the sense of meaningfulness, is the province, and moral responsibility, of leaders.

\section{Playing the Part}

From a personal standpoint, responsible leadership is a blend of commitment, understanding, and determination. This is partly a matter of self-conception, for... the responsible leader in a mature institution must transcend his specialism... And the assumption of command is a self-summoning process, yielding the will to know and the will to act in accordance with the requirements of institutional survival and fulfillment (Selznick, 1957: 142-143).

For Selznick, to be an institutional leader was not only to embody values and purpose in social structure and to infuse meaning into the life of others but also to internalize those values within oneself and to publicly represent them in one's conduct with others. A leader's actions are interpreted by others, both within and beyond the boundaries of the organization, as indicative of the organization's fundamental values and purpose, the beliefs central to the organization's existence, its raison d'être (Selznick 1957: 143). Leaders must therefore recognize they are playing a social role that has both technical and symbolic meaning. An institutional leader is not only a physical embodiment of the organization's values nor only a conduit channeling external 
technical exigencies into the organization. Instead, the institutional leader is actively aware that he or she plays a dynamic, multi-dimensional role at the boundary between the technical and the institutional, and between the organization and its environment. Because these boundaries are negotiable and fluid, institutional leaders serve as a proxy for their organizations and, as individuals, are judged by criteria similar to those used to evaluate these organizations and the values embodied therein. A final task of institutional leadership, therefore, is to perform the role in ways that are consistent with those expectations.

Some of the role expectations for the leader are explicit. Most obviously, individual leaders are expected to comply with the set of rules enforced by the political and legal context in the places they operate. For example, in many instances, governments have laws and regulations that constrain particular business and social-sector activities. By personally complying with these legal constraints, institutional leaders help maintain both the organization's and their own legitimacy. Other role expectations of a leader are implicit (Khurana, 2002). Leaders must conform to the informal social rules in the form of norms, values, and expectations that give a category of organizations (e.g., business, universities, government) their legitimacy and license to operate. Institutional leaders are expected to act in ways that ensure their organizations adhere to widely-held standards and beliefs that dictate how particular activities should be carried out, and prescribe the acceptable means for pursuing particular ends. For example, while we expect university presidents to run their organizations in economically-viable ways, there are also societal expectations about how universities should attain economic viability. We further expect university presidents to be paid less than executives in for-profit firms. Similarly, in a business setting, we expect audit firms to accurately represent the economic reality of the firms they audit. We do not expect audit firms to engineer financial reports that comply with a set of rules but not 
with the spirit of the rules and, as a consequence, give a misleading picture to investors, suppliers, or regulators about the health of a firm’s finances.

External constituents also scrutinize the micro-behaviors of leaders. They expect leaders to stylize themselves in ways consistent with the identity and values of the organization and the institutional category to which it belongs. Leaders risk being seen as illegitimate if their styles do not fit external expectations. External constituents evaluate a range of behaviors including words, dress, tone, body language, and silences to make evaluations about a leader's ability to play the role. Rare is the university president or board member of a Fortune 500 company, for example, who has a pierced lip or a visible tattoo. How leaders speak about their organizations, the processes by which they make decisions, and the kinds of people with whom they surround themselves are all examples of signals that leaders use to communicate conformity with external expectations.

Failure to play the role effectively threatens the legitimacy of the leader and the organization. For example, some new leaders, such as Harvard University’s young president Lawrence Summers, have a difficult time adjusting to the notion that they are playing a role, and flounder as a result. As Summers discovered, leaders cannot simply offer their personal opinions on issues. Rather, they are a symbol of their institution's values and are expected to speak in the ceremonial and collective voice of the institution. Summers' failure here led to doubts about the overall governance system at Harvard, with subsequent changes to this system and the selection of a new president who was much more aware and willing to play the part of the institutional leader. Even longtime CEOs have been censured for deviating from the expectations of their constituencies. Whole Foods CEO John Mackey was the subject of substantial criticism when he authored an editorial about health care reform expressing the personal opinion that Americans’ 
eating habits and lifestyle choices were at the root of the country's health problems and rising health care costs. His emphasis on personal responsibility ran counter to the values cherished by some of the company's external constituencies who organized a boycott to express their disapproval.

Other scholars have written about the role of leaders as symbolic representatives of their organizations and have emphasized the importance of "playing the part" in interactions with internal and external constituencies (e.g., Pfeffer, 1981; Pondy, 1978). Selznick’s approach differs from this work, however, in recognizing that playing the part must be more than just a strategic performance. Leaders need to authentically believe in the values they espouse for their organization as ends in themselves. To the extent that they are merely being calculative in articulating these values, they can undermine the benefits—-both moral and strategic—of defining values. Thus, even as leaders play the part for internal and external constituencies, Selznick argued that they must also strive to genuinely embody espoused values in their own conduct, and to develop identities that integrate these values. Without this internalization, followers view the leader as inauthentic (Bennis, 2002; George, 2003). For example, Robert Nardelli, hired by Chrysler to help turn around its operations, was immediately labeled as a hired gun CEO and "not a car guy." His attempts to pretend otherwise were seen by both employees and auto analysts as phony and disingenuous. On the other hand, Daniel Vasella, the head of the pharmaceutical firm Novartis, was seen as credible in defending pharmaceutical firms' attempts to protect their patents from illegal generics because of his background as a medical doctor committed to patients' wellbeing. 


\section{IMPLICATIONS FOR ORGANIZATIONAL THEORY AND LEADERSHIP RESEARCH}

Selznick’s influence on organizational theory was wide-reaching and profound. He described the dual nature of organizations as both economic entities, with the goal of achieving technical efficiency vis-à-vis the process of production, and "adaptive social structures" whose activities and survival are valued as meaningful ends in themselves. Contemporary scholars, especially those who write in the tradition of institutional research and whose theoretical apparatus rests on Selznick's work on the TVA, often downplay or ignore this key insight. As a result, current organizational perspectives that emphasize the material dimensions of organizational life often underplay or ignore the political, cultural, and value-laden elements. Meanwhile, institutional perspectives that privilege politics, culture, and values often trivialize material dimensions (Perrow, 1986: 265-270). And for both, the implications for organizational research and leadership education are often confusing or not spelled out.

The coexistence of and interplay among the material elements of organizations on the one hand, and the political, cultural, and value-laden elements on the other, was central to Selznick's intellectual project. He argued that leadership was vital to reconciling these seemingly oppositional forces. In Selznick's view, leaders recognize that organizations and their practices constitute meaning beyond their utilitarian functions and come to be valued as ends in themselves. They operate in the liminal space between the technical and institutional, and often between multiple and potentially conflicting institutional realms as well. Their skills as leaders are measured by how successfully they navigate and adjudicate the clash of forces inside and outside of the organization. 
Table 1 summarizes the technical and institutional elements of organizations and leadership. As we have noted above, Selznick understood the institutional domain to have a political as well as a cultural, value-laden dimension. In Table 1, we separate these two dimensions and compare them with the technical dimension in order to distinguish between the leadership tasks implied by each one. From a technical perspective, organizations are rational systems whose purpose is to efficiently accomplish established ends. Leadership activities are procedural in nature, and the leader operates relatively autonomously vis-à-vis the external environment. In contrast, as cultural and value-laden entities, organizations are moral orders in which integrity, not efficiency, is paramount. Leadership activities are symbolic in nature and the leader must be responsive to, not fully autonomous from, the external environment. Finally, organizations are also political arenas whose main purpose is survival. From this perspective, leadership is primarily tactical, and the leader engages in strategic action vis-à-vis the external environment. Selznick understood that the reality of organizational life, and of leadership, includes technical, cultural, and political elements. He also recognized that these elements are deeply intertwined. In both respects, his conception of leadership offers several implications for contemporary organizational research and leadership education, which we elaborate on below.

Insert Table 1 about here

\section{The Nature of Technical and Institutional Demands}

While institutional perspectives often treat the technical dimension of organizational life as socially-constructed (Meyer, 2010), Selznick’s work suggests that the technical is just as real as the cultural and political. Technical demands are not just myths. Leaders and organizational members alike experience them as real imperatives that must be addressed. For example, 
Edmonson (2007) describes a situation in which hospital leaders implemented quality and control systems for surgical procedures that reduced medical errors, thereby improving an important measure of performance, in this case saving lives. Rather than treating these initiatives as myth and ceremony, nurses and doctors actively modified their procedures and routines to implement new technologies that could improve data sharing and communication between healthcare providers. This does not deny the fact that technical practices and structures can become imbued with meaning. But Selznick emphasizes that they are not only, or even primarily, symbolic. They are material obligations and constraints which organizational actors must address.

Selznick’s work also highlights that values and meaning are not just socially-constructed myths (cf. Meyer \& Rowan, 1977). Neither are they arbitrary. They have a moral content to them and a basis in the ideals of society. Indeed, founding leaders often embed these values into organizational structures and practices such that the organization's technical system becomes an embodiment of its institutional values, not just the other way around. In the California cuisine movement, for example, sourcing locally-produced food is valued as a morally correct way of doing things, not as an efficient way. For Alice Waters, founder of the Chez Panisse restaurant and an early leader of the locally-sourced movement, values came first and the work of shaping the external environment-in this case, developing a local farming community that would grow food in ways that fit the organization's values (Guthman, 2003)—came later. Similarly, at firms such as Zappos and Whole Foods Market, employee participation in management decisions and the redistribution of profits to local communities are practices that originated in the values held by founding leaders (Frei \& Morriss, 2012; Marquis, Besharov, \& Thomason, 2011). 
In highlighting the reality of technical and institutional demands and the deep interconnections between them, Selznick's work suggests an alternative perspective on current issues in institutional theory. Selznick would recognize issues such as the presence of and potential conflict between multiple cultural meaning systems or societal logics (Thornton, Ocasio, \& Lounsbury, 2012), which create institutional pluralism and complexity (Greenwood, Raynard, Kodeih, Micelotta, \& Lounsbury, 2011; Kraatz \& Block 2008) and organizational hybridity (Battilana \& Lee, 2014; Besharov \& Smith, 2014). Yet the centrality of these phenomena in organizational life would be, for Selznick, a clear indicator of past leadership that was either weak or absent. More importantly, it would suggest a need and opportunity for more effective and responsible leadership to navigate amidst these forces. This calls for empirically grounded research on how leaders develop an organizational and self-identity that integrates potentially divergent goals and moralities held by internal and external constituencies and how they foster productive rather than destructive tensions between these potentially conflicting views of who the organization is and should be.

Selznick's work also reminds us that institutional leadership is equally important in organizations operating in less complex environments. In these organizations, leaders' efforts to uphold values while simultaneously attending to technical imperatives are not complicated by the challenges that arise from multiple and potentially conflicting values, making them excellent sites for research that further explores Selznick’s fundamental insights about leadership. The growing number of firms that adopt an explicit social mission not just as part of how they do business but as the technical business model (Boyd, Henning, Reyna, Wang, \& Welch, 2009; Haigh \& Hoffman, 2012; Smith, Gonin, \& Besharov, 2013) offer an example. Much like nonprofit organizations whose structures and operations are the embodiment of the organization's 
mission, these firms develop special know-how that embeds values and purpose into their production processes, recruitment and promotion systems, and product characteristics. At Burt's Bees, for example, a commitment to sustainability guides decisions about everything from hiring to sourcing to product packaging to facilities cleaning (Marquis, 2010). The alignment of values and technology has created distinctive strategic advantages and powerful brand integrity, and an important part of the success of such businesses stems from leaders imbuing the technology with a high social and value content. Yet the process by which this is done is not well understood. This represents a ripe area for future research, with significant theoretical as well as practical implications for understanding how leaders create organizations in which societal values are not only symbolic but are also deeply embedded within technical operations and functioning. A Selznickian perspective also holds promise for identifying problems that may arise in these organizations, such as mission drift or goal displacement (Ebrahim, Battilana, \& Mair, 2014), and for understanding how leaders can mitigate such problems or avoid them entirely.

\section{Managing the External Environment}

Peering outwards, leaders often see a fairly disordered system of actors with whom an organization has some kind of relationship. Each of the actors has different interests which they pursue with different degrees of determination. Each of the actors also has different kinds and degrees of leverage. The amount of leverage and importance may depend, at least in part, on the overall strategy the organization is pursuing. Absent institutional leadership, this complexity has the potential to create fragmentation, incoherence, conflict, goal-ambiguity, and instability. In such a setting, no group, inside or outside of the organization, is likely to be fully satisfied and political tensions and gamesmanship are likely to be high. 
In contrast, effective institutional leaders are adept at meeting the various technical and institutional imperatives in the context in which they operate. Indeed, the skill to placate external constituents may be a bare minimum requirement for organizational survival (Kraatz \& Block, 2008). More importantly, institutional leaders can use the diversity of interests confronting an organization to create complementarities across various stakeholders. This requires developing a framework for identifying and managing key stakeholders so that they support, rather than disrupt, the organization's mission. Leaders need to understand key stakeholders, noting the constraints they can impose and the opportunities or benefits they represent, and identifying people to serve as representatives to different stakeholder groups. They must analyze internal organizational capabilities and political support for their claims. They must also consider the relationships between and among stakeholders-how they are connected to, cooperate with, or compete with one another—as well as the resources the organization can offer to these stakeholders—-how it can contribute to the wellbeing of stakeholders in exchange for their support, and the tradeoffs involved in responding to various stakeholder claims.

These strategic aspects of managing the external environment are an important part of leadership and have been recognized as such (e.g., Washington, Boal, \& Davis, 2008). An equally important, though less commonly recognized, aspect of Selznick’s work, at least among organizational theorists, is his contention that managing the external environment involves cultural and value-laden as well as economic and political considerations, and his recognition that these are often intermingled. For example, Selznick understood that there are widely shared societal norms and values that are powerful in creating a standard against which organizations are compared, and that exert significant influence over the degree to which organizations can command the legitimacy needed to carry on with confidence, moral support, material and 
financial backing, and therefore a real prospect for survival and success. Stakeholders expect the organization to produce justifiable results. They expect its existence to improve economic or social welfare. To the extent that these expectations are not met, this raises questions about whether the organization and/or its activities are legitimate. Selznick emphasized that leaders play a key role in enabling organizations to be responsive to these expectations, and he suggests that this is a complex process that unfolds gradually, as the organization's value commitments are revealed and its fidelity to those commitments demonstrated. Incorporating these insights into research on leadership can enrich our understanding of the complexity and moral responsibility involved in managing the external environment.

\section{Developing Leadership Skills}

Scholars are increasingly recognizing that leadership is in part performance (Bennis, 2002). Because of the complex and chaotic context of today's globalized world, there is typically considerable contestation and maneuverability around leaders' motivations and trustworthiness. Leaders can use their skills to influence others' perceptions about these motivations or levels of trust. Classes on "authentic" leadership, which have becoming increasingly popular in MBA programs, take the view that individuals who are honest with themselves are likely to generate trust in others and foster organizational cultures that share information, encourage open communication, and uphold the organization's ideals. Because the concept of authentic leadership is so recent, we have very little research on how it is achieved or whether it is simply another social construct that has little content associated with it. We also do not understand the social or technical impact of authentic leadership on organizational effectiveness or organizational performance. Selznick's work can provide a useful starting point for research and 
teaching in this area. He recognizes that leadership is in part performance, but he suggests the performance is more effective, and more responsible, when it is accompanied by a true change in one's self-conception or identity. It is through their own moral development, he suggests, that leaders become capable of authentic performance in relations with others.

Our understanding of the skills involved in institutional leadership may also benefit from conceptualizing leadership in terms of social skill. Fligstein (2001) defines social skill as an individual's ability to induce cooperation by appealing to, and helping create, shared meanings and collective identities. Research on social movements suggests such skills are important in generating and changing systems of meaning (Ganz 2000). Yet the process by which social actors are able to provide an interpretation of a given situation and to frame courses of action that appeal to existing groups is not well understood. New ideas about the skills and tactics that social actors use to gain cooperation from others and reconcile otherwise conflicting tendencies in organizations have come to be of great interest and have significant implications for organizations. Framing, agenda-setting, and brokerage are all examples of skills that can be used to describe leadership in ways consistent with Selznick’s ideas.

As this discussion suggests, a Selznickian conception of leadership does not only apply to those who have the highest authority in organizations. Although this role was his explicit focus in LIA and other works, Selznick's core argument applies to anyone who occupies a position of authority in the formal organizational structure. For example, Besharov (2014) illustrates how frontline managers in the socially-responsible retailer "Natural Foods" developed organizational practices and routines to uphold values about organic food and environmental sustainability and worked to create meaningful experiences for their employees. Moreover, employees expected these managers to "play the part” in their personal conduct, and interpreted behavior that was 
inconsistent with organizational values as a moral violation. Developing the skills of an institutional leader, therefore, is essential at all levels of the organization, not just at the top.

\section{Leadership and Economic Performance}

Finally, Selznick’s work has important implications for our understanding of the relationship between leadership and economic performance. He clearly believed that by upholding institutional integrity, leaders could improve the long-term economic performance of firms. Contemporary scholarship similarly suggests that by at least appearing to uphold values and integrity, leaders may enhance firm performance. For example, Pfeffer (2007) has argued that to a large degree the value a CEO brings to an organization lies in his ability to inspire, communicate vision, and capture the affect of analysts and society in general. Yet others have suggested that searching for charismatic, and often outsider, CEOs has led firms to overlook highly-qualified and experienced insiders who might have been better equipped to manage the organization's technical demands (Khurana, 2002). This latter point resonates with Selznick’s recognition that even as integrity contributes to economic performance, so too is an organization's economic performance important for the maintenance of institutional values.

We recognize the need to consider the economic implications of institutional leadership, and we expect the debate over this issue to continue. Yet in conclusion, we want to emphasize the primacy of values and integrity. Even as he argued that upholding institutional integrity could enhance economic performance, Selznick made it his fundamental contention that, whether or not so doing is rewarded in the marketplace, it is simply the right thing for leaders to do. In this respect, we echo Podolny and colleagues (2005), who argue that infusing meaning into organizational life—and, we would add, maintaining institutional integrity—are important ends 
in and of themselves. Our hope is that by explicating the nature of institutional leadership, our chapter provides a starting point for empirical investigation of how leaders accomplish this and, in particular, of how they do so in the face of potentially conflicting technical demands. Perhaps it may also prompt scholars who emphasize either the technical or the political, cultural, and value-laden aspects of organizations to attend more closely to their interplay, both within organizations and at the interface of organizations and their environments. 


\section{REFERENCES}

Albert, S., \& Whetten, D. A. 1985. Organizational identity. In L. L. Cummings \& B. M. Staw (Ed.), Research in organizational behavior, vol. 7: 263-295. Greenwich, CT: JAI Press.

Ashforth, B. E., \& Reingen, P. H. 2014. Functions of dysfunction: Managing the dynamics of an organizational duality in a natural food cooperative. Administrative Science Quarterly, 59(3): 474-516.

Austin, J., \& Leonard, D. 2008. Can the virtuous mouse and the wealthy elephant live happily ever after? California Management Review, 51(1): 77-102.

Barnard, C. 1938. The functions of the executive. Cambridge: Harvard University Press.

Battilana, J., \& Dorado, S. 2010. Building sustainable hybrid organizations: The case of commercial microfinance organizations. Academy of Management Journal, 53(6): 1419-1440.

Battilana, J., \& Lee, M. 2014. Advancing research on hybrid organizing - insights from the study of social enterprises. The Academy of Management Annals, 8(1): 397-441.

Bennis, W. G. 2002. Leadership as a performing art. In The essential Warren Bennis: 333-341. San Francisco: Jossey-Bass.

Besharov, M. L. 2014. The relational ecology of identification: How organizational identification emerges when individuals hold divergent values. Academy of Management Journal, 57(5): 1485-1512.

Besharov, M. L., \& Smith, W. K. 2014. Multiple institutional logics in organizations: Explaining their varied nature and implications. Academy of Management Review, 39(3): 364-381.

Bogle, J. C., \& Levitt, A. J. 2012. The clash of the cultures: Investment vs. speculation. Hoboken, NJ: John Wiley \& Sons.

Boyd, B., Henning, N., Reyna, E., Wang, D., \& Welch, M. 2009. Hybrid organizations: New business models for environmental leadership. Sheffield, UK: Greenleaf.

Bromberger, A., R. 2011. A new type of hybrid. Stanford Social Innovation Review, Spring: 4953.

Bunderson, J. S., \& Thompson, J. A. 2009. The call of the wild: Zookeepers, callings, and the double-edged sword of deeply meaningful work. Administrative Science Quarterly, 54(1): 3257.

Cha, S. E., \& Edmondson, A. C. 2006. When values backfire: Leadership, attribution, and disenchantment in a values-driven organization. Leadership Quarterly, 17(1): 57-78. 
D'Aunno, T., Sutton, R. I., \& Price, R. H. 1991. Isomorphism and external support in conflicting institutional environments: A study of drug abuse treatment units. Academy of Management Journal, 34(3): 636-661.

Davis, G. F. 2010. Do theories of organizations progress? Organizational Research Methods, 13(4): 690-709.

Dobrow, S. R. 2013. Dynamics of calling: A longitudinal study of musicians. Journal of Organizational Behavior, 34(4): 431-452

Dobrow, S. R., \& Tosti-Kharas, J. 2011. Calling: The development of a scale measure. Personnel Psychology, 64(4): 1001-1049.

Dunn, M. B., \& Jones, C. 2010. Institutional logics and institutional pluralism: The contestation of care and science logics in medical education, 1967-2005. Administrative Science Quarterly, 55(1): 114-149.

Ebrahim, A., Battilana, J., \& Mair, J. 2014. The governance of social enterprises: Mission drift and accountability challenges in hybrid organizations. Research in Organizational Behavior.

Edmondson, A. C. 2003. Framing for learning: Lessons in successful technology implementation. California Management Review, 45(2): 34.

Fair Labor Association. 2012a. Foxconn investigation report.

Fair Labor Association. 2012b. PT glostar factory in indonesia.

Fligstein, N. 2001. Social skill and the theory of fields. Sociological Theory, 19(2): 105-125.

Follett, M. P. 1995. The essentials of leadership. In P. Graham (Ed.), Mary Parker Follett: Prophet of management: 163-181. Boston: Harvard Business School Press.

Foucault, M. 1995. Discipline \& punish: The birth of the prison (2nd ed.). New York: Random House.

Frei, F. X., \& Morriss, A. 2012. Uncommon service: How to win by putting customers at the core of your business. Boston: Harvard Business Press.

Ganz, M. 2000. Resources and resourcefulness: Strategic capacity in the unionization of California agriculture, 1959-1966. American Journal of Sociology, 105(4): 1003-1062.

George, B. 2003. Authentic leadership: Rediscovering the secrets to creating lasting value. San Francisco: Josey-Bass.

Gioia, D. A., Patvardhan, S. D., Hamilton, A. L., \& Corley, K. G. 2013. Organizational identity formation and change. The Academy of Management Annals, 7(1): 123-192. 
Gioia, D. A., Price, K. N., Hamilton, A. L., \& Thomas, J. B. 2010. Forging an identity: An insider-outsider study of processes involved in the formation of organizational identity. Administrative Science Quarterly, 55(1): 1-46.

Gioia, D. A., Schultz, M., \& Corley, K. G. 2000. Organizational identity, image, and adaptive instability. The Academy of Management Review, 25(1): 63-81.

Glynn, M. A., \& Rafaelli, R. 2013. What's so institutional about leadership? Theorizing leadership mechanisms of value infusion. Research in the Sociology of Organizations.

Grant, A. M. 2012. Leading with meaning: Beneficiary contact, prosocial impact, and the performance effects of transformational leadership. Academy of Management Journal, 55(2): 458-476.

Grant, A. M., \& Sumanth, J. J. 2009. Mission possible? The performance of prosocially motivated employees depends on manager trustworthiness. Journal of Applied Psychology, 94(4): 927-944.

Greenwood, R., Raynard, M., Kodeih, F., Micelotta, E. R., \& Lounsbury, M. 2011. Institutional complexity and organizational responses. Academy of Management Annals, 5: 317-371.

Gulick, L., \& Urwick, L. F. 1937. Notes on the theory of organization. Institute of Public Administration.

Guthman, J. 2003. Fast food/organic food: Reflexive tastes and the making of 'yuppie chow'. Social \& Cultural Geography, 4(1): 45-58.

Haigh N., \& Hoffman A.J. 2012. Hybrid organizations. The next chapter of sustainable business. Organizational Dynamics, 41(2): 126-134.

Hamilton, E. A. 2006. An exploration of the relationship between loss of legitimacy and the sudden death of organizations. Group \& Organization Management, 31(3): 327-358.

Harrison, S. H., Ashforth, B. E., \& Corley, K. G. 2009. Organizational sacralization and sacrilege. In A. P. Brief \& B. M. Staw (Ed.), Research in organizational behavior, vol. 29: 225254. Oxford, UK: Elsevier.

Heimer, C. A. 1999. Competing institutions: Law, medicine, and family in neonatal intensive care. Law \& Society Review, 33(1): pp. 17-66.

Heskett, J. 2011. The culture cycle: How to shape the unseen force that transforms performance. Upper Saddle River, NJ: FT Press.

Hwang, H., \& Powell, W. W. 2009. The rationalization of charity: The influences of professionalism in the nonprofit sector. Administrative Science Quarterly, 54(2): 268-298. 
Kanter, R. M. 2011. How great companies think differently. Harvard Business Review, November: 66-78.

Khurana, R. 2002. Searching for a corporate savior: The irrational quest for charismatic CEOs. Princeton, NJ: Princeton University Press.

Khurana, R. 2007. From higher aims to hired hands: The social transformation of American business schools and the unfulfilled promise of management as a profession. Princeton, NJ: Princeton University Press.

Koehn, N. F., Besharov, M. L., \& Miller, K. 2008. Starbucks Coffee Company in the 21st century. Boston: Harvard Business School.

Kotter, J. P. 1999. John P. Kotter on what leaders really do. Boston: Havard Business Review Press.

Kraatz, M. S. 2009. Leadership as institutional work: A bridge to the other side. In T. B. Lawrence, R. Suddaby, \& B. Leca (Ed.), Institutional work: Actors and agency in institutional studies of organizations: 59-91. New York: Cambridge University Press.

Kraatz, M. S., \& Moore, J. H. 2002. Executive migration and institutional change. The Academy of Management Journal, 45(1): pp. 120-143.

Kraatz, M., \& Block, E. 2008. Organizational implications of institutional pluralism. In R. Greenwood, C. Oliver, R. Suddaby,K.Sahlin-Andersson (Ed.), Handbook of organizational institutionalism: 243-275. London: Sage Publication.

Kraatz, M., Ventresca, M. J., \& Deng, L. 2010. Precarious values and mundane innovations: Enrollment management in American liberal arts colleges. Academy of Management Journal, 53(6): 1521-1545.

Krygier, M. 2012. Philip Selznick: Ideals in the world. Stanford, CA: Stanford University Press. Manning, P. K. 1977. Police work: The social organization of policing. Cambridge, MA: MIT Press.

March, J. G., \& Weill, T. 2005. On leadership. Oxford, UK: Wiley-Blackwell.

March, J., \& Olsen, J. 1976. Ambiguity and choice in organizations. Bergen: Univeritsforlaget.

Marquis, C. 2010. Burt's Bees: Balancing growth and sustainability. Boston: Harvard Business School.

Marquis, C., Besharov, M. L., \& Thomason, B. 2011. Whole Foods: Balancing social mission with growth. Boston: Harvard Business School. 
Martin, J. 1992. Cultures in organizations: Three perspectives. New York: Oxford University Press.

Marx, K. 1976. Capital: A critique of political economy. London: Penguin Books.

Merton, R. K. (Ed). 1952. Reader in bureaucracy. New York: Free Press.

Metcalf, H. C., \& Urwick, L. F. (Eds.). 1942. Dynamic administration: The collected papers of Mary Parker Follett. New York: Harper \& Row.

Meyer, J. W. 2010. World society, institutional theories, and the actor. Annual Review of Sociology, 36(1): 1-20.

Meyer, J. W., \& Rowan, B. 1977. Institutionalized organizations: Formal structure as myth and ceremony. American Journal of Sociology, 83(2): 340-363.

Michels, R. 1966. Political parties: A sociological study of the oligarchical tendencies of modern democracy. New York: Free Press.

Morrill, C. 2006. Institutional change and insterstitial emergence: The growth of alternative dispute resolution in American law, 1965 - 1995. In W. W. Powell \& D. Jones (Ed.), How institutions change. Chicago: University of Chicago Press.

Murray, F. 2010. The oncomouse that roared: Hybrid exchange strategies as a source of distinction at the boundary of overlapping institutions. The American Journal of Sociology, 116(2): 341-388.

Nadler, D., \& Tushman, M. 1997. Competing by design: The power of organizational architectures. New York: Oxford University Press.

Oliver, C. 1991. Strategic responses to institutional processes. Academy of Management Review, 16(1): 145-179.

O'Reilly, C. 1989. Corporations, culture, and commitment: Motivation and social control in organizations. California Management Review, 31(4): 9.

Perrow, C. 1986. Complex organizations: A critical essay (3rd ed.). New York: McGraw-Hill.

Pfeffer, J. 1981. Management as symbolic action: Creation and maintenance of organizational paradigms. In L.L. Cummings \& B.M. Staw (Eds.), Research in organizational behavior, vol. 3: 1-52. Greenwich: JAI Press.

Pfeffer, J. 1997. New directions for organization theory: Problems and prospects. New York: Oxford University Press. 
Pfeffer, J. 2007. What were they thinking? Unconventional wisdom about management. Boston: Harvard Business School Press.

Pfeffer, J. 2010. Building sustainable organizations: The human factor. Academy of Management Perspectives, 24(1): 34-45.

Podolny, J. M. 2011. A conversation with James G. March on learning about leadership. Academy of Management Learning \& Education, 10(3): 502-506.

Podolny, J., Khurana, R., \& Hill-Popper, M. 2005. Revisiting the meaning of leadership. Research in Organizational Behavior, 26: 1-31.

Pondy, L. R. 1978. Leadership is a language game. In M. W. McCall \& M. M. Lombardo (Eds.), Leadership: Where else can we go? Durham, NC: Duke University Press.

Pratt, M. G., \& Ashforth, B. E. 2003. Fostering positive meaningfulness at work. San Francisco: Berrett-Koehler.

Pratt, M. G., \& Kraatz, M. S. 2009. E pluribus unum: Multiple identities and the organizational self. In L. M. Roberts \& J. E. Dutton (Ed.), Exploring positive identities and organizations: Building a theoretical and research foundation: 385-410. New York: Psychology Press.

Purdy, J. M., \& Gray, B. 2009. Conflicting logics, mechanisms of diffusion, and multilevel dynamics in emerging institutional fields. Academy of Management Journal, 52(2): 355-380.

Reay, T., \& Hinings, C. R. 2009. Managing the rivalry of competing institutional logics. Organization Studies, 30(6): 629-652.

Rosso, B. D., Dekas, K. H., \& Wrzesniewski, A. 2010. On the meaning of work: A theoretical integration and review. Research in Organizational Behavior, 30: 91-127.

Salancik, G. R., \& Pfeffer, J. 1974. The bases and uses of power in organizational decision making: The case of a university. Administrative Science Quarterly, 19: 453-473.

Schein, E. H. 2004. Organizational culture and leadership (3rd edition ed.). San Francisco: Jossey-Bass.

Scott, W. R. 1992. Organizations: Rational, natural, and open systems (3rd ed.). Englewood Cliffs, NJ: Prentice Hall.

Selznick, P. 1949. TVA and the grass roots; a study in the sociology of formal organization. Berkeley, CA: Univ. of California Press.

Selznick, P. 1957. Leadership in administration: A sociological interpretation. Evanston, IL: Row Peterson. 
Selznick, P. 1992. The moral commonwealth: Social theory and the promise of community. Berkeley, CA: University of California Press.

Selznick, P. 1996. Institutionalism "old" and "new". Administrative Science Quarterly, 41(2, 40th Anniversary Issue): pp. 270-277.

Selznick, P. 2000. On sustaining research agendas: Their moral and scientific basis: An address to the western academy of management. Journal of Management Inquiry, 9(3): 277-282.

Selznick, P. 2008. A humanist science: Values and ideals in social inquiry. Stanford, CA: Stanford University Press.

Selznick, P., Nonet, P., \& Vollmer, H. M. 1980. Law, society, and industrial justice. Livingston, NJ: Transaction Publishers.

Smets, M., Morris, T., \& Greenwood, R. 2012. From practice to field: A multilevel model of practice-driven institutional change. Academy of Management Journal, 55(4): 877-904.

Smith, W. K., Gonin, M., \& Besharov, M. L. 2013. Managing social-business tensions: A review and research agenda for social enterprise. Business Ethics Quarterly, 23(3): 407-442.

Stout, L. 2012. The shareholder value myth. San Francisco: Berrett-Koehler Publishers.

Suddaby, R. 2010. Challenges for institutional theory. Journal of Management Inquiry, 19(1): 14-20.

Suddaby, R., Elsbach, K. D., Greenwood, R., Meyer, J. W., \& Zilber, T. B. 2010. Organizations and their institutional Environments_-Bringing meaning, values, and culture back in: Introduction to the special research forum. Academy of Management Journal, 53(6): 12341240.

Suddaby, R., \& Greenwood, R. 2005. Rhetorical strategies of legitimacy. Administrative Science Quarterly, 50(1): 35-67.

Taylor, F. W. 1911. The principles of scientific management. New York: Harper \& Brothers.

Thompson, J. 1967. Organizations in action: Social science bases of administrative theory. New York: McGraw-Hill.

Thornton, P. H., Jones, C., \& Kury, K. 2005. Institutional logics and institutional change in organizations: Transformation in accounting, architecture, and publishing. In Transformation in cultural industries, vol. 23: 125-170. Emerald Group Publishing Limited.

Thornton, P. H., Ocasio, W., \& Lounsbury, M. 2012. The institutional logics perspective: A new approach to culture, structure and process. Cambridge: Oxford University Press. 
Tolbert, P. S., \& Zucker, L. G. 1983. Institutional sources of change in the formal structure of organizations: The diffusion of civil service reform, 1880-1935. Administrative Science

Quarterly, 28(1): pp. 22-39.

Tucker, A. L., Nembhard, I. M., \& Edmondson, A. C. 2007. Implementing new practices: An empirical study of organizational learning in hospital intensive care units. Management Science, 53(6): 894-907.

Volcker, P. 2010. How to reform our financial system. New York Times.

Washington, M., Boal, K. B., \& Davis, J. N. 2008. Institutional leadership: Past, present, and future. In R. Greenwood, C. Oliver, K. Sahlin, \& R. Suddaby (Ed.), The SAGE handbook of organizational institutionalism: 721-735. Los Angeles: Sage.

Weber, K., \& Dacin, M. T. 2011. The cultural construction of organizational life: Introduction to the special issue. Organization Science, 22(2): 287-298.

Weber, M. 1964. The theory of social and economic organization (1st paperback ed.). New York: Free Press.

Weber, M. 1978. Economy and society, vol. III, G. Roth \& K. Wittich, eds. Berkeley: University of California Press.

Westphal, J. D., \& Zajac, E. J. 1994. Substance and symbolism in CEOs' long-term incentive plans. Administrative Science Quarterly, 39(3): pp. 367-390.

Westphal, J. D., \& Zajac, E. J. 1998. The symbolic management of stockholders: Corporate governance reforms and shareholder reactions. Administrative Science Quarterly, 43(1): pp. 127-153.

Whetten, D. A., \& Mackey, A. 2002. A social actor conception of organizational identity and its implications for the study of organizational reputation. Business \& Society, 41: 393-414.

Whetten, D. A. 2006. Albert and Whetten revisited: Strengthening the concept of organizational identity. Journal of Management Inquiry, 15(3): 219-234.

Woodward, J. 1965. Industrial organization: Theory and practice. London: Oxford University Press.

Zilber, T. B. 2002. Institutionalization as an interplay between actions, meanings, and actors: The case of a rape crisis center in Israel. The Academy of Management Journal, 45(1): 234254.

Zilber, T. B. 2006. The work of the symbolic in institutional processes: Translations of rational myths in Israeli high tech. The Academy of Management Journal, 49(2): 281-303. 
Zilber, T. B. 2011. Institutional multiplicity in practice: A tale of two high-tech conferences in israel. Organization Science, 22(6): 1539-1559. 
TABLE 1

Technical, Cultural, and Political Dimensions of Leadership

\begin{tabular}{|c|c|c|c|}
\hline & Technical & $\begin{array}{c}\text { Cultural and Value- } \\
\text { Laden }\end{array}$ & Political \\
\hline $\begin{array}{c}\text { Nature of the organization } \\
\text { Organizational values and } \\
\text { purpose }\end{array}$ & Rational system & Moral order & Political arena \\
$\begin{array}{c}\text { Nature of leadership } \\
\text { activities }\end{array}$ & Efficiency & Integrity & Survival \\
$\begin{array}{c}\text { Leader's relationship with } \\
\text { external environment }\end{array}$ & Autonomous & Symbolic \\
\hline
\end{tabular}

